\title{
FOTOGRAFI POTRET \\ WANITA PENAMBANG PASIR DI LERENG SELATAN GUNUNG MERAPI, DAERAH ISTIMEWA YOGYAKARTA
}

\author{
Arti Wulandari \\ Zulisih Maryani \\ Dosen Jurusan Fotografi, Fakultas Seni Media Rekam, ISI Yogyakarta \\ Jl. Parangtritis Km 6,5 Bantul, Yogyakarta \\ No. Hp.:+6285292999919, E-mail: artifajar@gmail.com \\ No.Hp.: 08157970619,E-mail: zulisihm8@gmail.com
}

\begin{abstract}
Abstrak
Ketegaran dan kesabaran yang luar biasa, sebagai sesama wanita, dari para wanita penambang pasir di Lereng Selatan Gunung Merapi, Daerah Istimewa Yogyakarta menjadi inspirasi untuk diungkapkan dalam karya fotografi dengan bentuk potret hitam putih karena potret bisa mewakili keadaan sebenarnya dari objek. Penciptaan ini bertujuan mengungkapkan kehidupan wanita penambang pasir di Lereng Selatan Gunung Merapi, Daerah Istimewa Yogyakarta dalam fotografi potret hitam putih dikaitkan dengan aspek teknis kreatif dan fungsi nilai sosialnya. Proses perwujudan mencakup tahap-tahap penciptaan dan media yang digunakan untuk mewujudkan karya seni fotografi potret yang tentunya membutuhkan bahan, alat, dan teknik. Prosedur pelaksanaan meliputi persiapan, pemotretan, proses editing, penentuan lay out, dan pencetakan hasil akhir. Karya penciptaan ini menampilkan karya-karya yang merupakan serangkaian fotografi potret wanita penambang pasir di Lereng Selatan Gunung Merapi, Daerah Istimewa Yogyakarta.Melalui foto-foto yang ditampilkan diharapkan dapat memberikan sudut pandang bagi masyarakat dalam mengapresiasi sosok wanita penambang pasir, melalui ketegaran dan kesabarannya yang luar biasa. Keunggulan karya ini adalah menampilkan foto potret wanita penambang pasir dengan hitam putih sehingga tampak lebih dramatis.
\end{abstract}

Kata kunci: fotografi potret, wanita penambang pasir, foto hitam putih, Lereng Selatan Gunung Merapi

\begin{abstract}
Portrait Photography of Female Sand Miners at the Southern Slope of Mount Merapi, Special Region of Yogyakarta. Obstinacy and remarkable patience, as fellow women, from all female sand miners in the Southern Slope of Mount Merapi, Special Region of Yogyakarta, became the inspiration to be expressed in the form of photographic works with black and white portrait because a portrait can represent the actual state of the object. The aim of this creation is to reveal the life of female sand miners in the Southern Slope of Mount Merapi, Special Region of Yogyakarta in black and white portrait photography associated with the aspects of creative technique and with the function of social value. The embodiment process includes the stages of creation and media that are used to create the works of art of portrait photography that will require materials, equipments, and techniques. Implementation procedures include the preparation, photo shooting, editing, determination of lay out, and the printing of the final results. This creative artwork features the works in a series of portrait photography of the female sand miners in the Southern Slope of Mount Merapi, Special Region of Yogyakarta. Through the photographs displayed, they are expected to provide viewpoints for society in appreciating the figure of female sand miners, through their outstanding obstinacies and patience. The excellence of this work is to show portrait photography offemale sand miners in black and white photography so that it will look more dramatic.
\end{abstract}

Keywords: portrait photography, female sand miners, black and white photo, Southern Slope of Mount Merapi 


\section{PENDAHULUAN}

Demi menghidupi sang anak agar bisa mengenyam pendidikan lebih tinggi dan bernasib baik, sejumlah wanita di Lereng Gunung Merapi rela menantang bahaya di sungai. Mereka rela bergelut dengan pasir dan batu, menantang banjir dan tanah longsor yang sewaktu-waktu bisa terjadi tanpa mereka sadari.

Wanita-wanita penambang pasir ini seakan tidak menghiraukan ancaman yang bisa terjadi sewaktu mereka menambang di sungai dan tebing-tebing tinggi. Bahkan mereka menambang tanpa menggunakan pelindung, hanya topi yang mereka gunakan untuk menghindari terik matahari. Tidak jarang mereka membawa anak-anak balita mereka di lokasi penambangan. Mereka mulai melakukan penambangan selepas Subuh hingga sore pukul 16.00 WIB. Dalam sehari mereka berhasil mendapatkan penghasilan $\mathrm{Rp} 25$ ribu hingga Rp 35 ribu. Penghasilan itu, sebagian disisihkan guna pendidikan anak.

Selama melakukan penambangan di Kali Gendol, musuh besar yang selalu menghadang adalah banjir lahar dingin sebab saat banjir turun, dipastikan mereka tidak dapat menambang. Selain itu, pasir yang telah mereka kumpulkan juga hanyut terbawa banjir. Ramainya penambangan di sepanjang Kali Gendol berawal dari erupsi besar Gunung Merapi pada tahun 2010. Pada tahun tersebut sepanjang sungai yang berhulu dari Gunung Merapi penuh dengan material pasir dan bebatuan. Hal itu yang kemudian menjadi rezeki bagi masyarakat sekitarnya bahkan masyarakat di luar kawasan Merapi. Erupsi Gunung Merapi yang terjadi tahun 2010 merupakan erupsi terbesar sepanjang 20 tahun terakhir, yang meluluhlantakkan semua yang ada di sekitar kawasan Gunung Merapi. Akan tetapi, di balik itu semua menjadi berkah dan ladang rezeki bagi masyarakat kawasan Merapi.

Pengamatan terhadap para wanita penambang pasir di Lereng Selatan Gunung Merapi, Daerah Istimewa Yogyakarta akan diungkapkan dalam bahasa gambar, yaitu foto khususnya foto seni dalam bentuk potret. Ketegaran dan kesabaran yang luar biasa, sebagai sesama wanita, menjadi inspirasi untuk diungkapkan dalam karya fotografi dengan bentuk potret hitam putih karena potret bisa mewakili keadaan sebenarnya dari objek.

Sebagaimana diungkapkan Soedjono (2006):

hasil "Fotografi potret merupakan pengabdian 'likeness' (kemiripan) jati diri figur manusia dalam bentuk dwimatra (gambar). Sebagaimana juga Mark Galer menyatakan bahwa potret fotografi adalah karya seni yang menampilkan manusia sebagai subjek dalam bentuk imaji dua dimensi: "Craft of representing a person in a single still image...". Dalam hal ini aspek manusia sebagai 'subjek foto' sangat dominan sehingga bentuk implementasinya sangat terbatas hanya pada diri manusia saja. Seandainya ada yang menggunakan benda atau binatang sebagai objek fotonya, maka karya foto tersebut tidaklah bisa disebut sebagai karya fotografi potret. Bagi seseorang yang mengatakan bahwa, "Ini Terry... potret binatang kesayanganku" sambil menunjukkan foto anjingnya, maka apa yang dilakukannya adalah sekedar upaya untuk 'memanusiakan' (to animate) hewan piaraannya ke tataran status manusia."

Dengan demikian, wanita penambang pasir di Lereng Selatan Gunung Merapi, Daerah Istimewa Yogyakarta, sebagai manusia dapat diwujudkan dalam fotografi potret hitam 
putih sebagai hasil representasi perekaman/ pengabdian 'likeness' (kemiripan) jati diri figur manusia dalam bentuk dwimatra (gambar). Penciptaan fotografi potret wanita penambang pasir ini dikaitkan dengan aspek teknis kreatif dan aspek fungsi nilai sosialnya. Hitam putih dipilih karena foto hitam putih mempunyai kesan dinamis dengan gradasi hitam ke putih terang atau disebut dengan zone system akan semakin menambah makna tersendiri dari sebuah foto. Foto hitam putih dapat mengungkapkan ekskpresi atau emosi untuk lebih meningkatkan nilai dramatis visual dari subjek foto.

Berdasarkan latar belakang yang telah dikemukakan, dapat dirumuskan bahwa permasalahan yang akan dibahas adalah bagaimana mengungkapkan kehidupan wanita penambang pasir di Lereng Selatan Gunung Merapi, Daerah Istimewa Yogyakarta dalam fotografi potret hitam putih dikaitkan dengan aspek teknis kreatif dan fungsi nilai sosialnya.

Secara teknis pengambilan objekfoto tanpa adanya pengaturan model atau subjek terlebih dahulu. Dengan demikian, foto dibuat apa adanya yang ada dilokasi, tampak alami tidak dibuat-buat dan pengambilan secara candid photography. Sesuai dengan pernyataan Nugroho (2006), bahwa candid photography adalah pemotretan yang dilakukan dengan objek sewajarnya (tanpa ada usaha rekayasa atau penyutradaraan) sehingga dapat diperoleh gambar (foto) yang lebih hidup, terkesan wajar, dan tidak dibuat-buat.

Karena dalam pemotretan mengutamakan momen, dalam pemotretan tersebut dilakukan dengan maksimal. Pemanfaatan dan kepekaan terhadap objek foto yang dianggapmenarik sangat dipersiapkan karena momen dalam suatu aktivitas sangat spontan dan cepat. Dalam Kamus
Fotografi, Nugroho (2006) mendefinisikan bahwa"memotret adalah mengabadikan peristiwa secepat kilat dalam satu gambar tunggal".

Membaca Fotografi Potret: Wacana, Teori, dan Praktik adalah buku yang mengulas fotografi potret karya Irwandi \& M. Fajar Apriyanto dan (2013). Buku ini merupakan sebentuk usaha untuk memberikan gambaran bagaimana melakukan pembacaan karya fotografi, khususnya fotografi potret. Maksud pembacaan dalam buku ini ialah upaya untuk memahami interaksi antara fotografer, aspekaspek teknis, identitas, serta aspek sosial budaya yang melingkupi proses penciptaaan foto potret sehingga menjadikannya bermakna. Asumsi yang dikembangkan di sini ialah bahwa aspek-aspek tersebut saling berkaitan sehingga memengaruhi wujud akhir sebuah karya.

Tesis Muji Soewasta (2004) "Studi tentang Konsep Penciptaan Fotografi Potret Selebriti Wanita pada Karya Andreas Darwis Triadi" mendeskripsikan segala hal yang mendasari proses penciptaan serta latar belakang kehidupan dan filosofi fotografer Darwis Triadi. Selain itu, juga merupakan upaya mengamati proses penciptaan fotografi potret selebriti wanita, dan tujuan serta fungsi, makna dan keunikan ciptaannya. Hasil penelitian ini menunjukkan bahwa fotografi potret karya Darwis Triadi benar-benar merupakan karya yang kaya pembaharuan yang mampu mewujudkan keindahan bentuk tubuh dan karakteristik selebriti wanita yang menjadi modelnya.

Irwandi (2008) menyusun tesis pengkajian seni "Foto Potret Karya Kassian Cephas: Kajian Estetis, Makna, dan Fungsi Sosialnya". Tesis ini bertujuan mengetahui korelasi antara segi estetis, makna, dan fungsi 
kehadiran fotografi potret dalam karyakarya Kassian Cephas, fotografer Indonesia pertama. Hal-hal yang diteliti meliputi aspekaspek estetika fotografi dalam fotografi potret, konstruk makna yang dapat terbaca berdasarkan konteks sosial politik dan budaya pada masa karya dibuat serta fungsi-fungsi sosial karya fotografi potret.

Berikut karya acuan dalam penciptaan karya fotografi ini.

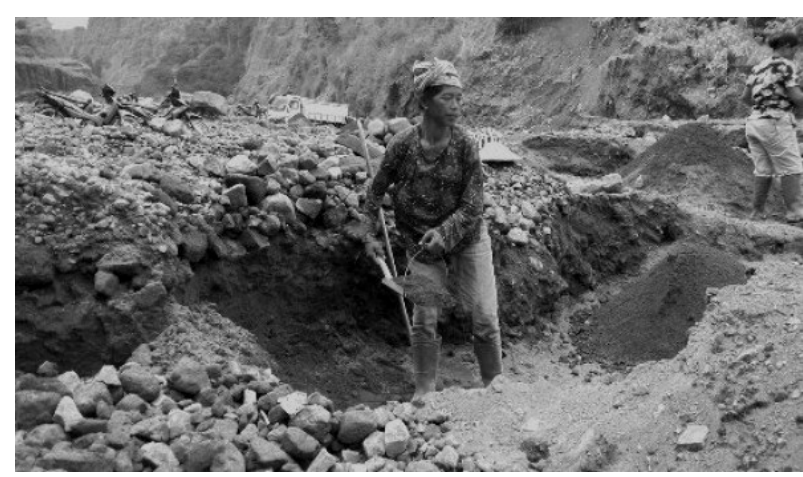

Foto acuan 1

Wanita penambang pasir dari Lereng Gunung Merapi sedang menambang pasir.

Sumber: (Dok.Timlo.net/ Nanin, diakses pada

8 April 2016, pukul 06.00 WIB)

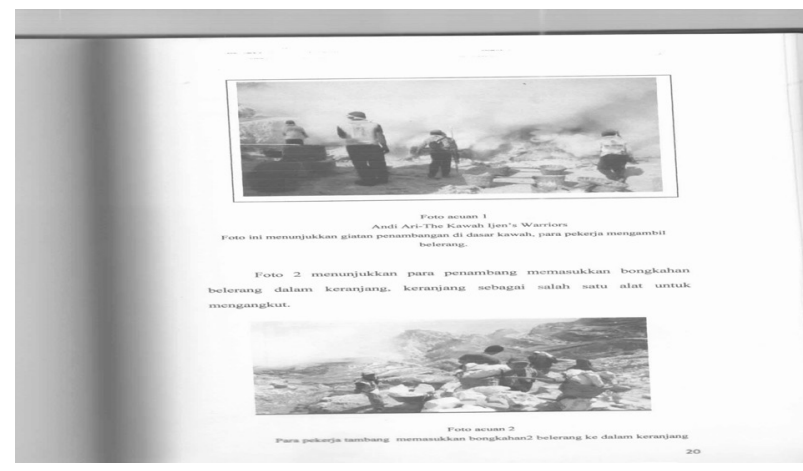

Foto acuan 2

Andi Ari - The Kawah Ijen's Wariors

Para pekerja tambang memasukkan bongkahan-bongkahan belerang ke dalam keranjang

\section{LANDASAN TEORI}

\section{Fotografi Potret}

'Secara etimologis, istilah 'POTRET' atau 'potrek' (Jawa) merupakan alih bahasa dari kata benda 'portrait' - portraiture (Inggris) yang berasal dari kata 'portraire' (Perancis) atau kata 'protahere' (Latin), yang artinya 'gambar' atau "PICTURE: especially a pictorial representation (as a painting) of a person usually showing his face" (Webster New Collegiate Dictionary dalam Soedjono, 2006).

Fotografi potret adalah fotografi tentang orang atau binatang. Tujuannya biasanya adalah untuk menonjolkan tampilan fisik, dan jika dilakukan dengan baik, bisa memunculkan sisi personalitas yang tidak pernah teramati sebelumnya (McGovern, 2003).

Nugroho (2006) menyebut istilah fotografi potret dengan foto potret, yaitu:

"Pemotretan wajah manusia secara close up, atau dalam format setengah atau $3 / 4$ badan.Padahal, kata portrait sendiri berasal dari bahasa Latin "protrahere" yang artinya mengekspresikan keluar.Ini berarti foto potret harus mampu menampilkan karakter atau ekspresi manusa dengan situasi lingkungannya. Artinya, keberadaan lingkungan juga berfungsi menonjolkan karakter manusia tersebut. Karakter tersebut bisa berasal dari manusianya sendiri atau juga manusia bersama lingkungan dan peristiwa yang ada di sekitarnya.Sebagai contoh bisa disebutkan di sini bahwa foto potret bisa dibuat di ruang kerja dengan penyertaan segala peralatan yang ada di ruang. Atau, seperti yang sering terlihat pada World Press Photo Contest, foto potret yang dibuat dalam negara yang sedang dilanda perang." 
2. Aspek Teknis Kreatif dan Aspek Personal, Sosial, \& Komersial Fotografi Potret

Dijelaskan oleh Soedjono (2006), fotografi potret tidak lepas dari aspek teknis kreatif dan aspek personal, sosial, \& komersial. Secara teknis, penampilan potret manusia diabadikan tidak hanya bagian wajahnya saja sebagai bentuk nyata dirinya tetapi bisa juga ditampilkan seperempat badan (pas-photo/ torso), separuh badan, dan seluruh tubuh. Sebuah karya potret secara kreatif diciptakan dan ditampilkan dalam berbagai jenis posisi (pose) objek fotonya/mode/the sitter, varian ukuran (size/format), ragam sisi pandang (angles) dan nuansa pewarnaan/kromasi yang beragam dalam bentuk penampilannya sebagai potret sosok tunggal (solo-portrait) maupun dalam potret sekelompok (group-portrait).

Aspek personal, sosial, \& komersial fotografi potret diuraikan Soedjono (2006) berkaitan dengan kehadiran foto potret, yang telah memungkinkan untuk diimplementasikan bagi bermacam tujuan dan fungsi secara personal maupun yang bernilai sosial dan komersial. Contoh aspek personal fotografi potret adalah menyimpan potret seseorang di dalam dompet dan orang tua yang merekam perkembangan anaknya dalam bentuk medium potret fotografi. Penampilan potret diri 'selfportrait' yang prosesnya dilakukan oleh sang fotografer sendiri dengan menggunakan prefocus dan self-timer, juga merupakan foto potret yang bernilai personal bagi sang fotografer. Aspek personal bisa juga dilihat dari sisi nilai kedirian hasil potret itu sendiri yang mampu menyiratkan sifat, jati diri, atau karakter pribadi sang modelnya. Hal ini dinilai merupakan karya foto potret yang berhasil manakala potret foto tersebut dapat merefleksikan lubuk hati yang terdalam dari objek fotonya. Keberadaan photographic booth atau photography vending machine yang diletakkan di mal-mal juga memiliki nilai personal karena secara instan bisa melakukan sesi pemotretan 'self-portrait' dengan berbagai sikap, pose, ekspresi, dan gaya dengan hasil serial beberapa foto potret diri. Dengan kemajuan teknologi fotografi digital, implementasi foto potret semakin luas. Nilai personal foto potret juga terlihat pada penggunaannya sebagai 'wall-paper' baik bagi tayangan monitor di komputer maupun pada tayangan telepon selular yang menyiratkan adanya 'personal attachment' atau nilai kedekatan dan simpati pribadi. Nilai personal foto potret bisa dilihat dari sisi fotografernya yang melihatnya sebagai suatu kenangan yang tak terlupakan karena satu dan lain hal peristiwa yang melatarbelakanginya.

Sebuah foto potret bernilai sosial manakala fungsi keberadaannya dikaitkan bagi pemenuhan keperluan fungsi sosial kehadirannya.Sebagai suatu 'tanda' sebuah foto potret dapat dimaknai sebagai representasi deskriptif tentang seseorang tertentu yang juga dapat dinilai memiliki makna identitas sosial. Status sosial seseorang juga dapat ditampilkan pada sebuah potret dengan kelengkapan kostum tertentu yang mengindikasikan etnis, profesi, atau jabatan seseorang karena pakaian yang dikenakannya.Bentuk foto potret lainnya yang juga bernilai sosial ialah ketika sebuah foto berfungsi sebagai elemen ilustratif bagi sebuah artikel atau berita yang termuat pada media cetak. Pada konteks lain, aspek sosial foto potret terlihat pada acara kampanye pemilu yang masing-masing kontestan menampilkan foto-foto calon kandidat mereka. Bentuk saji implementasinya bisa berupa berbagai medium yang disosialisikan pada masa kampanye, dari 
pin, stiker, poster, T-shirt, spanduk, dan lainlain yang menampilkan ragam bentuk foto potret yang ada.

Foto-foto potret dinilai sebagai medium bernilai komersial karena kehadirannya diorientasikan sebagai komoditas bernilai finansial.Karya-karya foto tersebut dari awal memang dikonsepkan sebagai medium yang dirancang memiliki standar tertentu untuk meraih kepentingan dan tujuan yang bernilai keuangan. Dari sisi bentuknya karya-karya foto ini tertampilkan dalam berbagai jenis cover atau halaman sampul: majalah, $\mathrm{CD}$, buku autobiography, poster, kalender, ilustrasi iklan cetak di surat kabar/majalah; billboard, maupun yang dijadikan sebagai merek produk tertentu (Jamu Nyonya Meneer), dll. Dari segi penciptaannya, sejak berkembannya foto potret pada abad XIX yang lalu, tampilnya foto-foto studio bagi pelayanan penciptaan foto potret merupakan indikasi pemanfaatannya sebagai komoditas berpotensi komersial.Paket-paket pelayanan studio-studio foto yang ditawarkan foto studio tidak saja membuat foto potret pribadi bagi kepentingan formal dan nonformal, tetapi sudah mengarah pada segmentasi kebutuhan tertentu, seperti paket-paket perkawinan, wisuda, dan ulang tahun. Penggunaan foto potret sebagai ilustrasi iklan juga merupakan bagian nilai komersial dari foto potret yang dikonsepkan sebagai elemen desain yang berfungsi sebagai 'center of interest' dan 'eye catcher' atau penarik pandang bagi tampilan iklan cetak. Bernilai komersial juga apabila kita bisa menghimpun foto-foto potret tokoh-tokoh publik yang sewaktu-waktu diperlukan dapat ditawarkan sebagai bisnis 'photo-stock' bagi kepentingan-kepentingan tertentu.

\section{Foto Hitam Putih}

Foto hitam putih mempunyai kesan dinamis dengan gradasi hitam ke putih terang atau disebut dengan zone system akan semakin menambah makna tersendiri dari sebuah foto. Lewis (1991) dalam buku Photojournalism, Content and Technique berpendapat: "The essence of a picture may be more easily understood in black and white without the added and sometimes confusing qualities of color." (Sebuah gambar mungkin akan sangat mudah untuk dipahami dalam hitam dan putih tanpa adanya suatu pemahaman yang terkadang membingungkan dengan warna itu sendiri). Pendapat senada juga dipaparkan Clement Cooper (2000) dalam katalog Hijaby Sister, yaitu "Black and white captures life so well. Better than any other medium." (Hitam putih menangkap kehidupan begitu baik, lebih baik daripada media yang lain.)

\section{Wanita Penambang Pasir}

Wanita adalah perempuan dewasa (Tim Penyusun Kamus Pusat Bahasa, 2007). Wanita penambang pasir adalah perempuan dewasa yang pekerjaannya menambang pasir.

\section{Lereng Selatan Gunung Merapi, Daerah Istimewa Yogyakarta}

Gunung Merapi (ketinggian puncak $2.930 \mathrm{~m} \mathrm{dpl}$, per 2010) adalah gunung berapi di bagian tengah Pulau Jawa dan merupakan salah satu gunung api teraktif di Indonesia. Lereng sisi selatan berada dalam administrasi Kabupaten Sleman, Daerah Istimewa Yogyakarta, dan sisanya berada dalam wilayah Provinsi Jawa Tengah, yaitu Kabupaten Magelang di sisi barat, Kabupaten Boyolali di sisi utara dan timur, serta Kabupaten Klaten di sisi tenggara. Kawasan hutan di sekitar puncaknya 
menjadi kawasan Taman Nasional Gunung Merapi sejak tahun 2004. Gunung ini sangat berbahaya karena menurut catatan modern mengalami erupsi (puncak keaktifan) setiap dua sampai lima tahun sekali dan dikelilingi oleh permukiman yang sangat padat. Sejak tahun 1548, gunung ini sudah meletus sebanyak 68 kali.Kota Magelang dan Kota Yogyakarta adalah kota besar terdekat, berjarak di bawah $30 \mathrm{~km}$ dari puncaknya. Di lerengnya masih terdapat permukiman sampai ketinggian 1700 $\mathrm{m}$ dan hanya berjarak empat kilometer dari puncak. Oleh karena tingkat kepentingannya ini, Merapi menjadi salah satu dari enam belas gunung api dunia yang termasuk dalam proyek Gunung Api Dekade Ini (Decade Volcanoes) (Wikipedia: Ensiklopedia Bebas, diakses pada Rabu, 12 April 2016, pukul 18.00 WIB). Lereng Selatan Gunung Merapi dalam penciptaan ini difokuskan di Kali Gendol, Dusun Kopeng, Kepuharjo, Cangkringan, Sleman, DIY.

\section{Teknik Fotografi dalam Fotografi Potret}

Menurut Leonardi (1997), dalam fotografi potret ada empat hal yang perlu diperhatikan, yaitu pose, harmoni, pencahayaan, dan ekspresi. Pose sangat penting nilainya bagi sebuah foto. Selain memberi jiwa pada foto, pose adalah rekaman gaya yang paling natural dari seseorang. Pose yang baik justru lahir dari sesuatu yang sangat alamiah dan akrab dengan kehidupan sehari-hari orang tersebut, misalnya cara tertawa, duduk, dan bekerja. Agar pose yang diberikan sesuai dengan karakter subjeknya, penulis perlu mendapat gambaran yang tepat tentang subjeknya. Seperti kebiasaan Sebastio Salgado dalam An Uncertain Grace (1990), kumpulan esai foto di berbagai negara tentang orang-orang kecil, dan Workers (1993) tentang kehidupan buruh kasar di 28 negara. Kekuatan pose dalam fotografi potret dan esainya tampil memuaskan mata penikmat seni foto dan masyarakat.

Sebuah foto yang baik memiliki harmoni atau keselarasan antara setiap unsur di dalamnya, warna satu dengan yang lainnya. Untuk mencapai keselarasan ini koordinasi pun diperlukan. Dalam fotografi potret, wajah adalah bagian terpenting yang harus menjadi titik perhatian (focus of interest) dan memiliki daya tarik.Contohnya sebuah senyuman, wajah yang kasar, dan wajah yang penuh misteri. Oleh sebab itu, perlu diusahakan agar baju atau perlengkapan lainnya jangan sampai lebih menonjol daripada wajah, tetapi ikut mendukung dalam menampilkan karya.

Fotografi potret bukanlah fashion yang hanya berlaku sesaat, melainkan rekaman gaya (style) yang paling baik, yang tidak pernah ketinggalan zaman. Keabadian inilah yang sesungguhnya ingin dimasukkan ke dalam potret.

Pencahayaan, yaitu cahaya dari depan, samping, atas, bawah, dan belakang merupakan salah satu unsur penting dalam foto. Fungsinya tidak sekadar mencahayai subjek, tetapi juga memperkuat karakter orang yang difoto.

Ekspresi, khususnya dalam fotografi potret, sangat penting artinya karena ekspresilah yang menghidupkan dan memberi jiwa bagi sebuah foto. Pada dasarnya setiap karya yang dibuat penulis adalah juga ekspresi penulis sendiri, yaitu memotret sesuai dengan apa yang dipikirkan dalam benak dan hati, yaitu tentang sisi kemanusiaan dari wanita penambang pasir di Lereng Selatan Gunung Merapi, Daerah Istimewa Yogyakarta dan estetika dari potret.

Untuk membantu proses penciptaan, dalam karya ini dibuat dengan menggunakan 
metode EDFAT. Metode EDFAT (Entire, Detail, Frame, Angle,Time) yang diperkenalkan oleh "Walter Cronkite School of Journalism and Telecommunication Arizona State University', merupakan konsep pengembangan fotografi pribadi (www.wikipedia.org).

\section{Metode EDFAT}

Metode EDFAT adalah suatu metode pemotretan untuk melatih optis melihat sesuatu dengan detail yang tajam,membantu proses percepatan pengambilan keputusan terhadap suatu kondisi visual yang bercerita. Dalam praktiknya metode EDFAT biasanya menjadi sangat penting digunakan dalam fotografi jurnalistik, tetapi dalam penciptaan karya ini tidak ada salahnya menggunakan metode ini sebagai bahan acuan. Adapun tahap-tahap yang dilakukan pada setiap unsur dari metode ini adalahsuatu proses dalam mengincar bentuk visualitas suatu peristiwa bernilai berita.

Adapun unsur-unsur dalam metode EDFAT adalah:

1. Entire (E), yaitu suatu keseluruhan pemotretan yang dilakukan begitu melihat suatu peristiwa atau bentuk penugasan lain. Untuk mengincar atau mengintai dan memilih bagian-bagian untuk dipilih menjadi objek.

2. Detail (D), yaitu suatu pilihan atas bagian tertentu dari keseluruhan pandangan sebelumnya (entire). Tahap ini adalah suatu pilihan pengambilan keputusan atas sesuatu yang dinilai paling tepat sebagai point of interest.

3. Frame (F), yaitu suatu tahapan dimana kita mulai membingkai suatu detail yang telah dipilih. Fase ini mengantar seseorang untuk mengenal arti suatu komposisi, pola, tekstur, dan bentuk subjek pemotretan dengan baik dan akurat.

4. Angle (A), yaitu tahap dimana pemilihan sudut pandang pemotretan. Objek menjadi dominan, ketinggian, kerendahan, level mata kiri dan kanan serta cara melihat.

5. Time $(\mathrm{T})$, yaitu tahap penyinaran atau cahaya dengan kombinasi yang tepat antara diagfragma, kecepatan rana, dan kepekaan terhadap keempat tingkat yang telah disebutkan sebelumnya. Pengetahuan teknis membekukan gerakan atau memilih ruang tajam adalah satu syarat dasar yang sangat diperlukan.

\section{METODE PENCIPTAAN}

\section{Tahap Eksplorasi}

a. Ide Penciptaan

Ide merupakan titik awal dimulainya penciptaan ini.Ide untuk menjadikan wanita penambang pasir di Lereng Selatan Gunung Merapi, DIY ini berawal dari pengamatan penulis terhadap aktivitas wanita penambang pasir di aliran sungai Gendol di Desa Kopeng, Kepuharjo, Cangkringan, Sleman, Daerah Istimewa Yogyakarta.

Ketegaran dan kesabaran yang luar biasa, sebagai sesama wanita, menjadi inspirasi bagi penulis untuk diungkapkan dalam karya fotografi dengan bentuk potret hitam putih karena potret bisa mewakili keadaan sebenarnya dari objek.Pengamatan terhadap para wanita penambang pasir di Lereng Selatan Gunung Merapi, Daerah Istimewa Yogyakarta ingin penulis ungkapkan dalam bahasa gambar, yaitu foto khususnya foto seni dalam bentuk potret. 
b. Pengumpulan Data

Untuk mendukung pemotretan dan penyusunan laporan dibutuhkan datadata mengenai hal-hal yang berhubungan dengan wanita penambang pasir di Lereng Selatan Gunung Merapi, Daerah Istimewa Yogyakarta. Data-data tersebut diperoleh dengan:

1) Studi Lapangan atau Observasi Kancah

Observasi kancah adalah pergi ke kancah, melakukan pengamatan, dengar keluhan dari orang-orang yang bekerja di kancah (Hadi, 1984). Kancah, dalam penciptaan karya foto ini adalah lokasi hunting, yaitu sepanjang kali Gendol yang berada di Dusun Kopeng, Kepuharjo, Cangkringan, Sleman, Daerah Istimewa Yogyakarta.

2) Studi Pustaka

Studi kepustakaan yang dilakukan adalah guna mencari bahan rujukan penulisan dan kemampuan analisis terhadap objek foto dan memberikan wacanawacana terhadap bidang keilmuan secara umum dan fotografi pada khususnya.

Sumber tertulis tentang wanita penambang pasir di Lereng Selatan Gunung Merapi, DIY diperolehi dari internet.Pencarian wacana tentang bidang ilmu fotografi diperlukan untuk mengetahui konsep dan teori tentang fotogarfi potret dan fotografi hitam putih.

3) Wawancara
Data tentang wanita penambang pasir di Lereng Gunung Merapi, Daerah Istimewa Yogyakarta ini didapat dari beberapa narasumber. Sebagian besar narasumber yang dijadikan responden adalah para penambang pasir dan tokoh masyarakat di Dusun Kopeng, Kepuharjo, Cangkringan, Sleman, Daerah Istimewa Yogyakarata. Wawancara dilakukan dengan Lurah Kepuharjo, Heri Soeprapto, yang dapat memberikan informasi bermanfaat dan akurat dikarenakan sebelum menjadi lurah, beliau adalah penambang pasir juga di Kali Gendol.

Koentjaraningrat

mengungkapkan bahwa wawancara adalah cara yang dipergunakan seseorang untuk tujuan tertentu jika ingin mendapatkan keterangan atau pendirian secara lisan dari seorang responden dengan cara-cara bercakap-cakap berhadapan dengan orang tersebut.

Wawancara langsung dengan wanita penambang pasir dan tokoh masyarakat di Lereng Selatan Gunung Merapi, DIY adalah langkah paling tepat dan cepat untuk mendapatkan data yang diinginkan.

\section{Tahap Eksperimentasi}

Tahap eksperimentasi dalam penciptaan karya ini menyangkut pelaksanaan pemotretan di lapangan yang dilakukan secara berulang-ulang. Berdasar referensi dan observasi dilakukan, untuk memudahkan 
pemotretan dibuatlah daftar rencana pemotretan atau shot script. Shot script ini sangat berguna untuk menentukan apa yang harus dipotret dahulu sehingga tidak terjebak dalam satu rutinitas saja. Dengan shot script ini juga diketahui mana yang kurang dan dapat segera dibenahi dengan jangka waktu yang relatif singkat. Peralatan fotografi yang digunakan adalah kamera DSLR merk Canon EOS 7D, kamera Canon G16 Kit, Lensa merk Canon lens EF 24-70mm $\mathrm{f} / 2.8$, memory card Merek SanDisk, hard disc external, dan komputer. Teknik pemotretan yang diterapkan adalah ruang tajam (depth of field),pemilihan komposisi, dan kecepatan rana.

\section{Tahap Sintesis}

Setelah melalui tahap eksplorasi dan tahap eksperimentasi, yaitu tahap persiapan yang matang dan penguatan konsep karya, kemudian dilanjutkan dengan pemotretan. Hasil pemotretan yang tersimpan dalam memory card dipindah ke dalam hard disc data storage. Sekembalinya dari lokasi hunting, data foto yang berada dalam storage harus dipindahkan ke dalam hard disc komputer. Pemindahan ini dimaksudkan untuk lebih memudahkan dalam proses editing untuk dijadikan foto bercitra hitam putih. Hal ini dikarenakan dasar dari kamera digital adalah berwarna.

Memotret menggunakan film hitam putih akan mendapatkan hasil hitam putih. Kamera digital yang digunakan dalam pemotretan karya ini tidak bisa secara langsung menghasilkan foto hitam putih, tetapi yang didapat adalah foto berwarna. Oleh sebab itu, perlu adanya suatu pengubahan dari warna ke gambar hitam putih.

Proses editing ini menggunakan program pengolah foto digital yang ada di komputer. Pengolahan dari gambar berwarna menjadi hitam putih di komputer melalui beberapa tahapan dan beberapa cara melalui beberapa program. Selanjutnya untuk mencapai hasil yang maksimal dalam rentang gradasi abu-abu mengacu pada penerapan zone system. Rentang gradasi dari putih sampai ke hitgam dengan melewati gradasi abu-abu dapat dicapai dengan baik dengan mengatur gelap terang dan kontras dalam proses pengolahan foto di dalam komputer.

Tahap seleksi dilakukan untuk memilih hasil foto yang sesuai dengan tema. Foto-foto yang dinilai tidak layak atau kurang sesuai dengan tema akan disisihkan terlebih dahulu. Hal ini dilakukan untuk mendapatkan hasil akhir yang maksimal.

\section{Tahap Penyelesaian}

Tahap selanjutnya adalah tahap penyelesaian yang mencakup upaya untuk mewujudkan keseluruhan hasil pengolahan citra berbentuk soft file atau data digital menjadi citra berbentuk print out. File foto dicetak dengan printer digital berbahan flexy front light. Jenis printer yang dipakai adalah printer indoor. Untuk kepentingan laporan penelitian ini foto dicetak dengan kertas foto untuk menghasilan cetakan warna yang seperti diharapkan. 


\section{PEMBAHASAN}

Dalam penciptaan karya foto ini, banyak sekali gagasan atau ide yang ingin diungkapkan. Akan tetapi, karena keterbatasan waktu tidak semua gagasan dapat direalisasikan ke dalam wujud karya foto. Karya penciptaan ini menampilkan karya-karya yang merupakan serangkaian fotografi potret wanita penambang pasir di Lereng Selatan Gunung Merapi, Daerah Istimewa Yogyakarta. Melalui fotofoto yang ditampilkan diharapkan dapat memberikan sudut pandang bagi masyarakat dalam mengapresiasi sosok wanita penambang pasir, melalui ketegaran dan kesabarannya yang luar biasa.

Keunggulan karya ini adalah menampilkan foto potret wanita penambang pasir dengan hitam putih sehingga tampak lebih dramatis. Pemakaian komposisi balance informal dan formal untuk lebih memudahkan penghayatan penikmat seni agar karya lebih mudah dipahami maksudnya dan dinikmati. Berikut karya-karya fotografi potret wanita penambang pasir di Lereng Selatan Gunung Merapi, Daerah Istimewa.

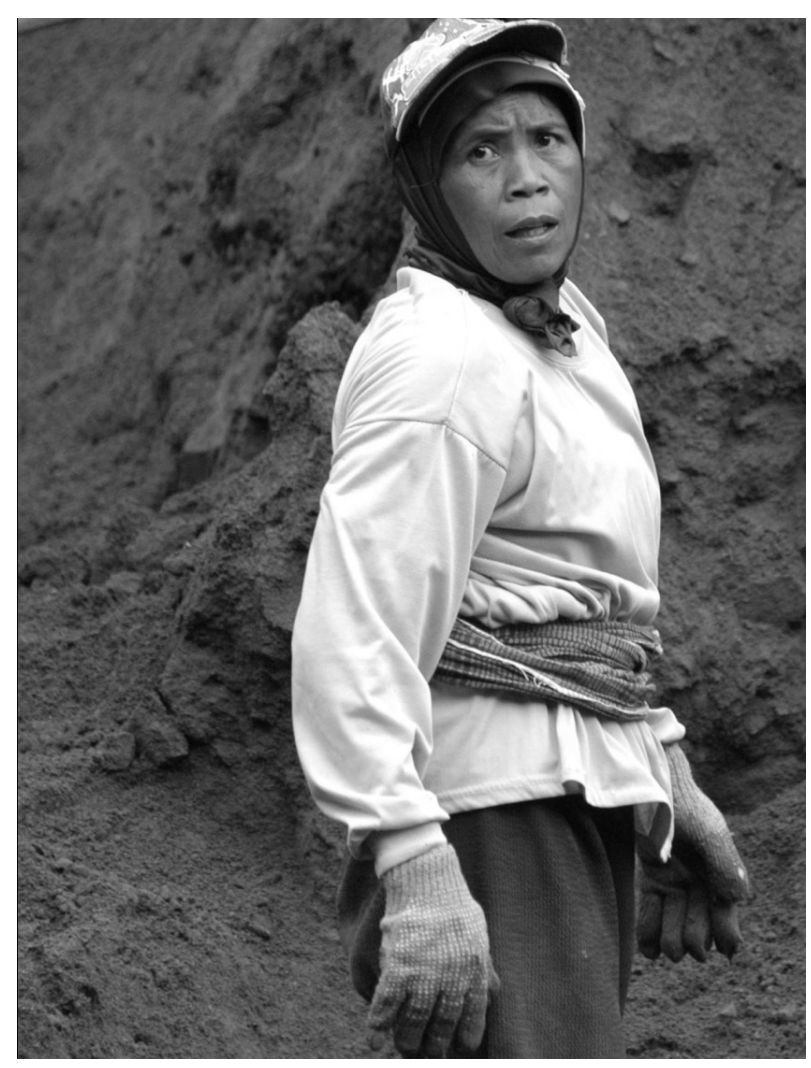

Foto 1

Tumini, 2016

Tumini adalah seorang penambang pasir wanita yang juga seorang ibu dengan empat orang anak yang masih kecil. Ia menambang pasir sejak 15 tahun yang lalu semenjak Gunung Merapi meletus. Dari menambang pasir inilah ia membantu kehidupan ekonomi keluarganya. Setiap hari ia harus berhadapan dengan pekerjaan ini, yang sebenarnya merupakan pekerjaan para lelaki. Terlihat dari raut wajahnya yang merasakan lelah dan pilunya bekerja seharian di area pertambangan, namun ia rela menguras tenaganya demi kehidupan anak-anaknya.Teknis: speed $1 / 125$, diafragma f/7.1, dan ISO 100. 


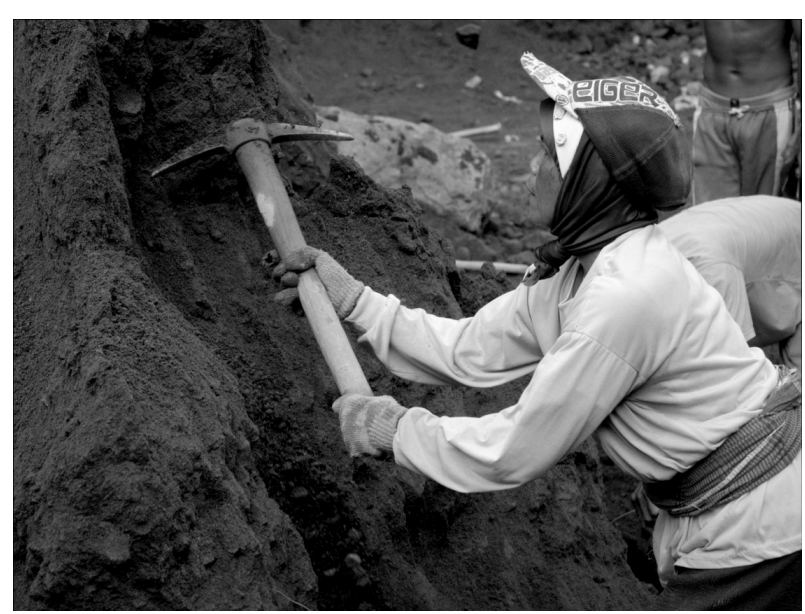

Foto 2

Tumini dengan Plancong, 2016

Plancong adalah istilah bahasa Jawa, kegunaannya di daerah penambang pasir adalah untuk mencangkul tebing pasir. Ketika tebing pasir mulai longsor, pasir dan batu akan berjatuhan, dan setelah itu penambang akan mulaimemisahkan antara batu dan pasir tersebut, kemudian dipilih sesuai jenisnya. Plancong ini biasanya memiliki bobot yang cukup berat bagi siapa saja yang belum pernah menggunakannya. Namun, bagi para penambang pasir yang ada di sekitar area penambangan pasir, memegang plancong ini sudah menjadi hal yang biasa. Terlebih lagi bagi para penambang wanita, mereka terlihat kuat dan berani ketika sedang menggunakan plancong tersebut. Padahal bisa saja sewaktu-waktu plancong yang mereka gunakan mengenai diri mereka sendiri.Teknis: speed 1/125, diafragma f/7.1, dan ISO 100.

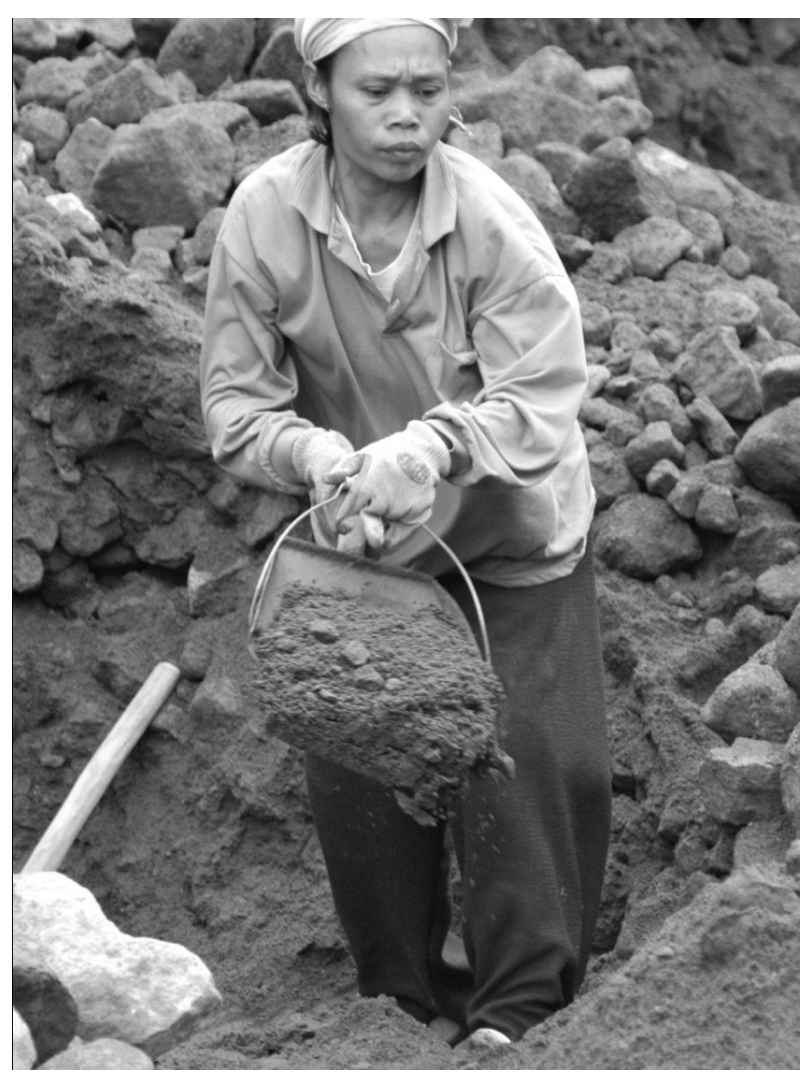

Foto 3

Tugiyem dengan Senggrong, 2016

Senggrong merupakan sebuah alat yang terbuat dari plat besi yang biasa digunakan oleh para penambang pasir untuk memindahkan pasir. Setelah para penambang mengeruk tebing pasir dengan menggunakan plancong, mereka memindahkan hasil reruntuhannya ke tempat yang lain dengan menggunakan alat ini. Akan tetapi, para wanita rela menguras tenaganya demi kehidupan anak-anaknya di area pertambangan, biasanya mereka menggunakan sarung tangan agar ketika bekerja tangan mereka tidak terluka terkena batu atau tangan bergesekan dengan alat yang mereka gunakan. Teknis: speed 1/60, diafragma f/4, dan ISO 100. 


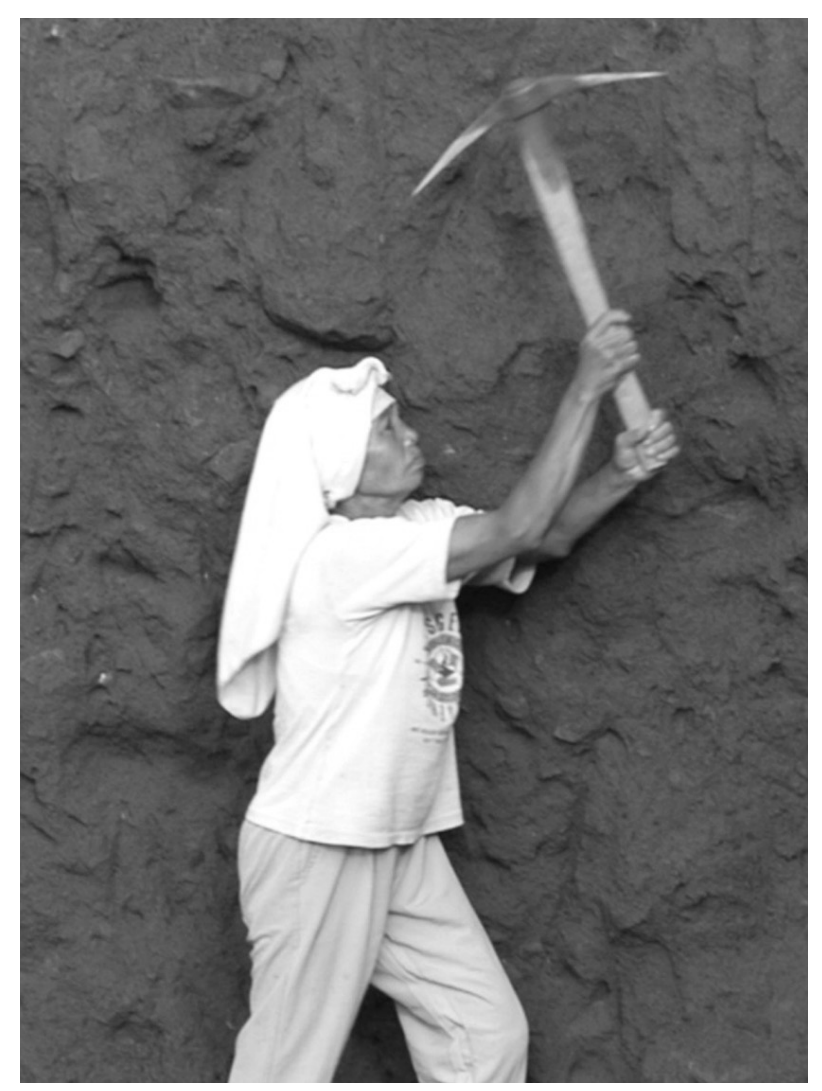

Foto 4

Waginem sedang Mengikis, 2016

Waginem, seorang penambang wanita sedang mengeruk tebing pasir dengan menggunakan plancong. Terlihat dari tangannya, otot-otot yang mengeras untuk menahan genggaman plancong agar tidak terlepas. Sebenarnya yang dilakukannya ini sangat berbahaya untuk dirinya. Bisa saja sewaktu-waktu ketika sedang mengeruk, runtuhan dari tebing pasir tersebut mengenai dirinya dan bisa menimbunnya. Walaupun begitu, meskipun sudah terlihat sudah lanjut usia, ia tetap memiliki semangat yang terlihat dari perjuangannya dalam mengeruk tebing pasir tersebut. Semua ini dilakukan demi membantu kondisi ekonomi keluarganya di rumah. Teknis: speed 1/60, diafragma f/7.1, dan ISO 100.

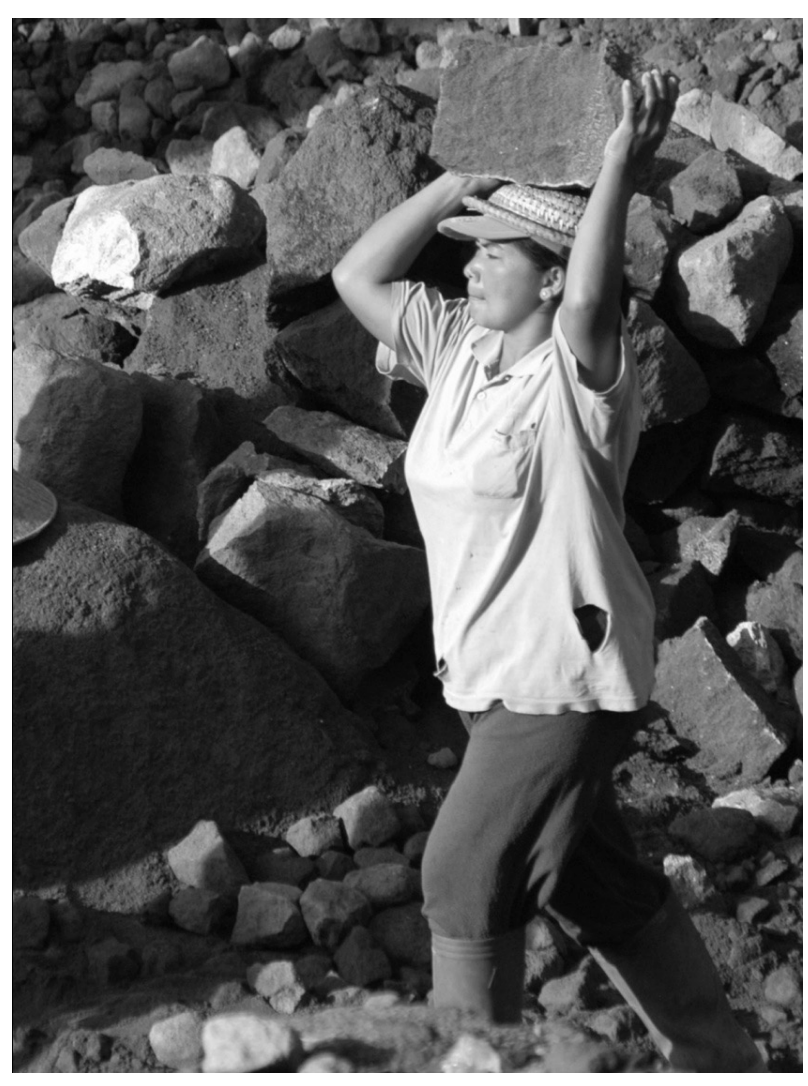

Foto 5

Sri yang Super Kuat, 2016

Seorang penambang wanita, Sri, sedang membawa bongkahan batu yang cukup besar di atas kepalanya. Walaupun kepalanya hanya dilapisi topi dan tangan tanpa menggunakan sarung tangan, ia tetap terlihat kuat membawa bongkahan batu tersebut ke tempat truk penampungan. Padahal berat dari batu yang ia angkut bisa mencapai 10 kilogram, bahkan bisa lebih dari itu. Pekerjaan ini sebenarnya sangat membahayakan dirinya, namun ia tetap melakukan pekerjaannya dengan semangat demi membantu kehidupan ekonomi keluarganya. Teknis: speed 1/125, diafragma f/7.1, dan ISO 100. 


\section{SIMPULAN}

Latar belakang penciptaan karya fotografi ini adalah kegigihan dan kesabaran wanita penambang pasir di Lereng Selatan Gunung Merapi, Daerah Istimewa Yogyakarta. Karya diwujudkan dalam potret hitam putih. Hambatan yang terjadi selama proses penciptaan karya semua dapat terlewati dengan lancar. Tujuan penciptaan karya ini adalah mengungkapkan kehidupan wanita penambang pasir di Lereng Selatan Gunung Merapi, Daerah Istimewa Yogyakarta dalam fotografi potret hitam putih dikaitkan dengan aspek teknis kreatif dan aspek fungsi sosial untuk menggugah sisi kemanusiaan penikmat foto dan masyarakat.

Penciptaan karya fotografi ini mempunyai berbagai banyak keterbatasan dan masih jauh dari sempurna sehingga saran dan kritik yang membangun sangat diperlukan untuk proses berkarya selanjutnya.

\section{KEPUSTAKAAN}

Hadi, S. (1984). Metodologi Research. Yogyakarta: Yayasan Penerbitan Fakultas Psikologi UGM.

Irwandi. (2008). Foto Potret Karya Kassian Cephas: Kajian Estetis, Makna, dan Fungsi Sosialnya. Program Pascasarjana ISI Yogyakarta.

Koentjaraningrat. (1983). Metode-Metode Penelitian Masyarakat. Jakarta: PT Gramedia.

Leonardi, I. (1997). Foto Portrait. Fotomedia.

Lewis, G. (1991). Photojournalism, Content and Technique. California: McGrawHill.

McGovern, T. (2003). Belajar Sendiri Fotografi Hitam Putih dalam 24 Jam. Yogyakarta: Penerbit ANDI.

Nugroho, R. A. (2006). Kamus Fotografi. Yogyakarta: Penerbit ANDI.

Soedjono, S. (2006). Pot-Pourri Fotografi. Jakarta: Penerbit Universitas Trisakti.
Tim Penyusun Kamus Pusat Bahasa. (2007). Kamus Besar Bahasa Indonesia. Jakarta: Pusat Bahasa. 